V.S. Petrushin, Y.R. Plotkin, R.N. Yenoktaiev, N.S. Prokopenko

\title{
RESEARCH OF DYNAMIC CHARACTERISTICS OF INDUCTION MOTORS IN ELECTRIC DRIVES WITH MATCHING TRANSFORMER AND REDUCER
}

Introduction. The variety of electric drives, the performance characteristics of which correspond to the set requirements of consumers while ensuring reliable and economical operation for a certain time resource, characterizes the variety of circuit solutions, including using matching transformers and reducers. Problem. The use of matching transformers and reducers units significantly changes the performance characteristics of the electric drive. Most articles are devoted to modeling an electric drive without such elements. It is advisable to consider simulations of electric drives using these elements. Methodology. In the models of matching transformers and reducers, the initial data are used, which determine both the functional properties and the mass and size parameters. The latter provide an opportunity to consider the economic aspects of the electric drive. For the correct calculation of the energy balance of the electric drive, the efficiency of the elements under consideration is taken into account. Results. The use of the developed algorithms for modeling the dynamic modes of two induction motors in electric drives operating on a specific load diagram, with the connection of a matching transformer and reducers, is considered. Dependencies of efficiency and power factor of motors have allowed to determine the medium cyclic energy indicators. The mass- size and cost indicators of variants of electric drives were found, which made it possible to calculate the average cyclic reduced costs of electric drives. Practical value. The possibility of choosing the best variant of the drive based on various indicators, including the minimum amount of energy losses per year, is substantiated. References 17, tables 2, figures 8.

Key words: induction motor, load cyclogram, reducer, transformer, mathematical model, average cyclic criteria, energy indicators, reduced costs.

Розглянуто використання розроблених алгоритмів для моделювання динамічних режимів двох асинхронних двигунів в електроприводах, щи працюють на певну циклограму навантаження, при включенні узгоджувальних трансформатора і редуктора. Враховано мінливість параметрів схем заміщення двигунів, пов'язана зі зміною насичення магнітних кіл $i$ витісненням струмів в обмотках роторів. Отримано $i$ зіставлені динамічні характеристики струмів і потужностей, споживаних двигунами. Залежності ККД $і$ коефіцієнта потужності двигунів дозволили визначити середньоциклічні енергетичні показники. Знайдено масогабаритні $і$ вартісні показники варіантів електроприводів, що дало можливість, при відомих середньоциклічних енергетичних показниках приводів, розрахувати середньоциклічні приведені витрати електроприводів. Обтрунтовано можливість вибору крацого варіанту приводу за вищевказаними показниками, а також за мінімумом втрат електроенергії за рік. Бібл. 17, табл. 2 , рис. 8.

Ключові слова: асинхронний двигун, циклограма навантаження, редуктор, трансформатор, математична модель, середньоциклічні критерії, енергетичні показники, приведені витрати.

Рассмотрено использование разработанных алгоритмов для моделирования динамических режимов двух асинхронных двигателей в электроприводах, работающих на определенную циклограмму нагрузки, при включении согласующих трансформатора и редуктора. Учтено непостоянство параметров схем замещения двигателей, связанное с изменением насыщения магнитных цепей и вытеснением токов в обмотках роторов. Получены и сопоставлены динамические характеристики токов и моцностей, потребляемых двигателями. Зависимости КПД и коэффициента мощности двигателей позволили определить среднециклические энергетические показатели. Найдены массогабаритные и стоимостные показатели вариантов электроприводов, что дало возможность, при известных среднециклических энергетических показателей приводов, рассчитать среднециклические приведенные затраты электроприводов. Обоснована возможность выбора лучщего варианта привода по выщеуказанным показателям, а также по минимуму потерь электроэнергии за год. Библ. 17, табл. 2, рис. 8.

Ключевые слова: асинхронный двигатель, циклограмма нагрузки, редуктор, трансформатор, математическая модель, среднециклические критерии, энергетические показатели, приведенные затраты.

Introduction. A variety of electric drives (ED), whose performance characteristics meet the specified requirements of consumers while ensuring reliable and economical operation for a certain time resource, characterizes the variety of circuit solutions, including using matching transformers and reducers. The value of the drive load may vary in time, which is characterized by the mode of operation described by the load cyclogram. Heating of the electric machine depends on the operation mode, i.e. on the ratio of the duration of periods of operation and pauses between them or periods of operation with full or partial load, on the frequency of switching on the machine and the nature of the flow of transients. Along with the standard modes of operation [1], non-standard ones are also possible $[2,3]$. The standard ones are characterized by different time indicators (duration of switching on, duration of load, duration of operation, frequency of switching on, etc.).

The correct choice of electric drive should provide high energy performance during operation, indicating its rational use. When commensurate operation time of induction motors (IM) in steady and transient (start, transfer from one load to another) modes, transients have

(C) V.S. Petrushin, Y.R. Plotkin, R.N. Yenoktaiev, N.S. Prokopenko 
a significant impact on the performance of electric drives. In some cases, IMs are operated in intermittent modes associated with alternating motor operation for loads of different values. Transients in IM were considered by a number of authors [2, 4]. At the same time, the rejection of the use of certain assumptions in the simulation of dynamic modes of IM allows us to refine the mathematical models (MM) [5].

The use of matching transformers and reducers significantly changes the performance characteristics of the ED. Most of the papers are devoted to ED modeling without such elements in both static and dynamic modes [2, 4-7]. In a number of works [8-11], the analysis is performed taking into account transformers and reducers. It is advisable to consider modeling ED using these elements.

The goal of the paper is to use the developed algorithms to simulate the dynamic modes of induction motors in electric drives with matching transformers and reducers and to substantiate the possibility of comparing the considered electric drives in terms of weight, cost, energy and cost parameters, as well as on the cost of electricity to choose a rational drive option.

Problem definition. All considered drives operate on a certain load cyclogram and provide almost the same number of revolutions on the mechanism. In the models of matching transformers and reducers, initial data are used, which determine both functional properties and weight, size and cost parameters. The latter provide an opportunity to consider the economic aspects of the ED. The functional ones are: for a reducer - a gear ratio $\left(i_{r e d}\right)$, for a transformer - a transformation ratio $\left(k_{t r}\right)$. The correctness of the calculation of the energy balance of the electric drive requires the use of the efficiency of the considered elements $\left(\eta_{\text {red }}, \eta_{t r}\right)$. Modeling ED with the connection of reducers and transformers in static and dynamic modes, the rotational speed $\left(n_{\text {mech }}\right)$ and torque $\left(M_{\text {mech }}\right)$ on the drive mechanism, the power consumed by the drive $\left(P_{E D}\right)$, the drive efficiency $\left(\eta_{E D}\right)$, the power of the load mechanism $\left(P_{\text {mech }}\right)$ are determined. In addition, it seems possible to calculate the weight, size, and cost parameters of the entire ED using any of the considered components.

Expressions that take into account the connection of the reducer and transformer in the ED when considering static modes, have the form:

$$
\begin{gathered}
n_{\text {mech }}=\frac{n}{i_{\text {red }}}, \\
M_{\text {mech }}=M_{I M} \cdot i_{\text {red }} \cdot \eta_{\text {red }}, \\
P_{\text {mech }}=P_{I M} \cdot \eta_{r e d}, \\
P_{E D}=P_{1}+\left(1-\eta_{t r}\right) \cdot P_{1}, \\
\eta_{E D}=\eta_{I M} \cdot \eta_{t r} \cdot \eta_{r e d}, \\
U_{2}=\frac{U_{1}}{k_{t r}},
\end{gathered}
$$

where $n$ is the motor speed; $M_{I M}$ is the torque on the motor shaft; $P_{I M}$ is the useful mechanical power on the motor shaft; $P_{1}$ is the consumed active motor power; $U_{1}$ is the primary voltage of the transformer; $U_{2}$ is the secondary voltage of the transformer.

Mathematical models used to study transient electromagnetic and electromechanical processes in induction motors are based on systems of nonlinear differential equilibrium equations for voltages and currents in a system of transformed coordinates $[6,7]$ :

$$
\begin{gathered}
\frac{d}{d t} \Psi_{s \alpha}=u_{s \alpha}(t)-r_{s} d(t)\left[x_{r}(t) \Psi_{s \alpha}(t)-x_{M}(t) \Psi_{r \alpha}(t)\right], \\
\frac{d}{d t} \Psi_{s \beta}=u_{s \beta}(t)-r_{s} d(t)\left[x_{r}(t) \Psi_{s \beta}(t)-x_{M}(t) \Psi_{r \beta}(t)\right] \\
\frac{d}{d t} \Psi_{r \alpha}=\left[-p \omega_{r} \cdot \Psi_{r \beta}(t)-r_{r}(t) d(t)\left[x_{S}(t) \Psi_{r \alpha}(t)-\right.\right. \\
\left.-x_{M}(t) \Psi_{s \alpha}(t)\right], \\
\frac{d}{d t} \Psi_{r \beta}=\left[p \omega_{r} \cdot \Psi_{r \beta}(t)-r_{r}(t) d(t)\left[x_{S}(t) \Psi_{r \beta}(t)-\right.\right. \\
\left.-x_{M}(t) \Psi_{s \beta}(t)\right], \\
\frac{d \omega_{r}}{d t}=\frac{1}{J}\left\{\frac{3 p}{2} d(t) x_{M}(t)\left[\Psi_{s \beta}(t) \Psi_{r \alpha}(t)-\Psi_{r \beta}(t) \Psi_{s \alpha}(t)\right]-\right. \\
\left.-M_{L}\left(\omega_{r}\right) /\left(i_{r e d} \cdot \eta_{r e d}\right)\right\},
\end{gathered}
$$

where $\Psi_{s \alpha}(t), \Psi_{s \beta}(t), \Psi_{r \alpha}(t)$, and $\Psi_{r \beta}(t)$ are the flux linkages of the stator and rotor windings of the machine, respectively, along the axes $\alpha$ and $\beta ; \omega_{r}$ is the motor angular rotation speed; $p$ is the number of pairs of poles; $J$ is the total moment of inertia of the drive, reduced to the motor shaft; $M_{L}(t)$ is the time dependence of the mechanism resistance; $r_{s}, r_{r}(t), x_{s}(t), x_{r}(t), x_{M}(t)$ are the active resistances and the total reactances of the stator and rotor windings and the mutual induction resistance, and all of which, except for $r_{s}$, change at each integration step; $d(t)$ is the auxiliary variable $d(t)=\left[x_{s}(t) \cdot x_{r}(t)-\left(x_{M}(t)\right)^{2}\right]^{-1}$; $u_{s \alpha}(t)$ and $u_{s \beta}(t)$ are the instantaneous values of the voltages along the $\alpha$ and $\beta$ axes, which are determined by the voltage amplitude $U_{m}$ and the angular position of the generalized voltage vector $\varphi_{1}$ :

$$
u_{s \alpha}(t)=U_{m}(t) \cdot \cos \left(\varphi_{1}\right), \quad u_{s \beta}(t)=U_{m}(t) \cdot \sin \left(\varphi_{1}\right) .
$$

The expressions connecting the instantaneous values of currents and flux linkages are as follows:

$$
\begin{aligned}
& i_{s \alpha}(t)=d(t) \cdot\left[x_{r}(t) \Psi_{s \alpha}(t)-x_{M}(t) \Psi_{r \alpha}(t)\right], \\
& i_{s \beta}(t)=d(t) \cdot\left[x_{r}(t) \Psi_{s \beta}(t)-x_{M}(t) \Psi_{r \beta}(t)\right],
\end{aligned}
$$

where $i_{s \alpha}, i_{s \beta}$ are the stator currents along the axes $\alpha$ and $\beta$. Instantaneous stator current value:

$$
i_{1}(t)=\sqrt{\frac{1}{2} \cdot\left[i_{s \alpha}(t)^{2}+i_{s \beta}(t)^{2}\right]} .
$$

A mathematical model built on the basis of the above differential equations allows to calculate the rotational frequencies, currents in the phases of the windings, electromagnetic torques, losses. 
In each of the equations, nonlinear coefficients take place - the motor parameters varying at each operating point, including due to the effects of saturation of the magnetic system and current displacement in the rotor winding $[12,13]$. One of the approaches to the analysis of the dynamic characteristics of IM involves the preliminary determination of these factors for the necessary operating points. Therefore, before analyzing the transient process, the calculations of steady-state regimes are carried out in order to obtain the values of all the parameters of the equivalent circuit, taking into account the current displacement in the rotor winding and the magnetic core saturation for the necessary operating points. For this purpose, MMs of steady-state modes are used. When calculating the dynamic modes, the changes at each step of the system integration are taken into account, i.e. at certain points, the characteristics of the transition from one torque of load to another, the parameters of the equivalent circuit. When implementing this approach, an increase in the level of MM adequacy is provided.

In a number of publications [14-16], in contrast to the classical theory, according to which the values of powers are calculated as integral, instantaneous values of powers are used. Then the conditional active power consumed by the motor in dynamic modes under the condition of sinusoidal supply voltage is calculated through instantaneous values of voltages and currents:

$$
p_{1}^{\prime}(t)=\frac{3}{2} \cdot\left[u_{s \alpha}(t) \cdot i_{s \alpha}(t)+u_{s \beta}(t) \cdot i_{s \beta}(t)\right] .
$$

The actual consumed active power $p_{1}$ is more than conditional one by the amount of the unaccounted losses (the main ones in the magnetic core $\Delta p_{\text {st base, }}$ the additional ones in the magnetic core $\Delta p_{\text {st add }}$, mechanical ones $\Delta p_{\text {mech }}$, additional ones $\left.\Delta p_{\text {mech }}\right)$ :

$$
\begin{aligned}
& p_{1}(t)=p_{1}^{\prime}(t)+\Delta p_{\text {st base }}(t)+\Delta p_{\text {st add }}(t)+ \\
& +\Delta p_{\text {mech }}(t)+\Delta p_{\text {add }}(t) .
\end{aligned}
$$

The power at the motor shaft can be determined through flux linkages and currents using the rotor speed value:

$$
\begin{aligned}
& p_{I M}(t)=\omega_{r} \frac{3 p}{2}\left[i_{r \beta}(t) \Psi_{r \alpha}(t)-i_{r \alpha}(t) \Psi_{r \beta}(t)\right]- \\
& -\Delta p_{\text {mech }}(t)-\Delta p_{\text {add }}(t) .
\end{aligned}
$$

The instantaneous value of efficiency is determined by the ratio of the instantaneous values of useful power on the motor shaft $p_{I M}$ to the consumed active power $p_{1}$.

As the drive selection criteria, the mass, dimensions, cost of the motor or drive, average cyclic reduced manufacturing and operating costs $\left(R C_{m c}\right)$, average cyclic energy indicators (efficiency and power factor) can be used, or a generalized criterion can be applied, taking into account the above criteria as components. Conventionally, the criteria can be divided into two groups: weight and size and cost; energy and costly. Selection results vary with different criteria used or with their different components in the generalized criteria, and also depend on the assigned coefficients of significance of these components. When calculating the criteria, their values in transient operating modes can be taken into account. This approach allows to make a choice for both modes of operation, in which the duration of transient modes is much less than the duration of operation in steady-state modes, and for modes with commensurability of the above durations.

In the case of taking into account transients, the energy-cost group of criteria for the motor or drive is determined by:

$$
\begin{aligned}
\eta_{m c I M(E D)} & =\frac{1}{t_{\text {end }}-t_{\text {start }}} \cdot \int_{t_{\text {start }}}^{t_{\text {end }}} \eta_{I M(E D)}(t) d t, \\
\cos \varphi_{m c I M(E D)} & =\frac{1}{t_{\text {end }}-t_{\text {start }}} \cdot \int_{t_{\text {start }}}^{t_{\text {end }}} \cos \varphi_{I M(E D)}(t) d t, \\
R C_{m c I M(E D)} & =\frac{1}{t_{\text {end }}-t_{\text {start }}} \cdot \int_{t_{\text {start }}}^{t_{\text {end }}} R C_{I M(E D)}(t) d t,
\end{aligned}
$$

where $t_{\text {end }}$ is the cycle end time; $t_{\text {end }}$ is the cycle start time.

With a known full cost of the motor cim the value of the criterion is defined as:

$$
R C_{I M}=\left(\operatorname{cim}+C_{r I M}\right)\left[1+T_{N}\left(k_{d e}+k_{s}\right)\right]+C L_{I M},
$$

where $C_{r I M}$ is the cost of expenses for reactive power compensation, $\mathrm{UAH} ; C L_{I M}$ is the cost of electricity losses for the year, UAH; $T_{N}$ is the standard payback period of the motor, years; $k_{d e}$ is the share of costs for depreciation; $k_{s}$ is the share of maintenance costs for motor operation.

For common industrial IM, the following values are accepted: $T_{N}=5$ years, $k_{d e}=0.065, k_{s}=0.069$. Then $R C_{I M}=1.67\left(\mathrm{cim}+C_{r I M}\right)+C L_{I M}$, where $C_{r I M}=C_{c r e} P_{1}\left(\operatorname{tg} \varphi_{1}-\right.$ - 0.484) and $C L_{I M}=C_{c a e} P_{1}\left(1.04-\eta_{I M}\right), C_{c a e}$ is the coefficient taking into account the cost of active energy losses, which is a product of cost of $1 \mathrm{~kW} \cdot \mathrm{h}$ of electricity during the service life of the motor $(0.05$ USD per $\mathrm{kW} \cdot \mathrm{h})$, the number of motor operation hours per year (2100), the number of years of operation before major repairs (5) and the ratio of the relative motor load (1.0), $C_{c r e}$ is the coefficient taking into account the cost of reactive energy compensation and representing the product of the cost of $1 \mathrm{kVAr}$ of the reactive power of compensating devices (15 USD for $1 \mathrm{kVAr}$ ), the coefficient of motor participation in the maximum load of the system $(0.25)$ and the ratio of the relative load. Similarly, at the known cost of the entire electric drive ced, the reduced costs of the drive $R C_{E D}$ are determined.

If as a selection criterion to use such an energy indicator as efficiency, energy-saving operation of the motor will be provided.

Results of investigations. In accordance with the above-mentioned, the DIMDrive code, similar to the DIMASDrive software [17], was developed at the Department of Electric Machines of the Odessa National Polytechnic University. The code is based on system 
principles, allowing to take into account the presence of certain possible components of the electric drive. In this regard, along with the IM models (for the steady state based on the T-shaped equivalent circuit, for the dynamic mode on the system of differential equations of a generalized machine), the load diagram $M(t)$ is included in the complex project model, and if necessary, models of transformer and reducer (between the motor and the load) matching voltage values of the network and the motor. Motor models involve the consideration of machines of various designs, degrees of protection, ventilation systems, types of rotors, etc. and take into account the change in the parameters of the equivalent circuit of the motor due to the saturation of the steel of the magnetic core and the displacement of currents in the motor windings, the presence of main and additional losses in steel in static and dynamic modes of the motor operation, the presence of higher spatial harmonics of the magnetic field. The analysis of electromagnetic, electromechanical, energy, thermal processes during the IM operation for various in value and mode of operation the load is provided. The code allows to implement a comprehensive analysis of the operation of IM, on the basis of which all the most important aspects of motor operation are considered.

The above software was used to simulate the operation of motors and electric drives in solution of this production problem.

The load is described by the following cyclogram: $2 \mathrm{~s}-50 \mathrm{~N} \cdot \mathrm{m}, 1 \mathrm{~s}-98 \mathrm{~N} \cdot \mathrm{m}$. Four variants of electric drives are considered at supply voltage of $380 \mathrm{~V}$ and network frequency of $50 \mathrm{~Hz}$ which is reflected in Fig. 1.

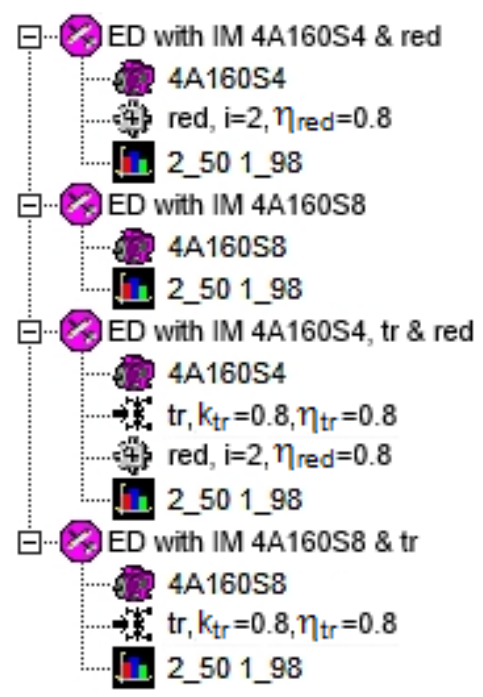

Fig. 1. Window of options of electric drives of the DIMDrive software

Motors 4A160S4 and 4A160S8 are used. In different variants there were different total moments of inertia, taking into account the moments of inertia of the motor and drive mechanism (ED with 4A160S4 $-0.3 \mathrm{~kg} \cdot \mathrm{m}^{2}$, ED $4 \mathrm{~A} 160 \mathrm{~S} 8-0.5 \mathrm{~kg} \cdot \mathrm{m}^{2}$ ). To ensure the same speed of rotation of the mechanism, the reducers are included in the variants with the 4A160S4 motor. Reducer parameters are shown in Fig. 2. For simplification the weight, size and cost parameters of the reducer are taken conditionally equal to 100 .

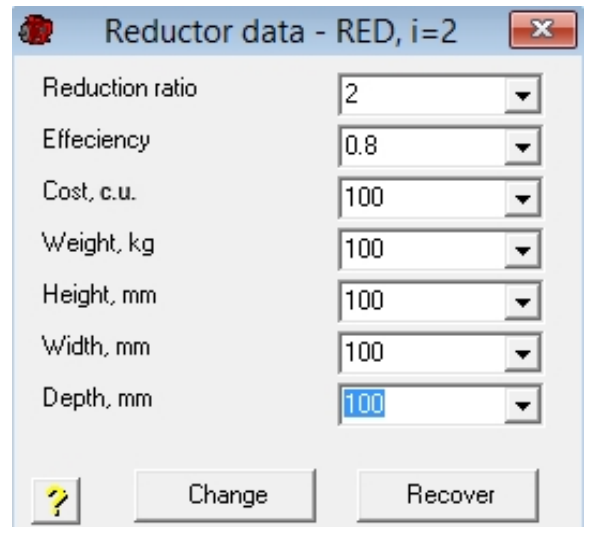

Fig. 2. Window of reducer parameters of the DIMDrive software

In two variants, a transformer was used at the drive input, the parameters of which are shown in Fig. 3. To simplify, the weight, size, and cost parameters of the transformer are taken conditionally equal to 100 . To obtain $\cos \varphi_{m c E D}$ values, the calculation transformer power factor is used $\left(k_{\text {ptrc }}=0.8\right)$ :

$$
\cos \varphi_{\mathrm{mc} E D}=\cos \varphi_{m c I M} \cdot k_{p t r c} .
$$

The performed thermal calculations (the maximum torque from the cyclogram for the steady state is set) showed the temperature of the motor stator winding exceeding the permissible value in the ED with IM 4A160S8 with transformer (Fig. 4). Therefore, this drive option is not considered further. The numbering of the characteristics corresponds to the variant numbering of the electric drives in Table 1, namely: 1 - ED with IM 4A160S4 with a reducer; 2 - ED with IM 4A160S8 without reducer and transformer; 3 - ED with IM 4A160S4 with reducer and transformer; 4 - ED with IM 4A160S8 with transformer.

\begin{tabular}{|c|c|c|}
\hline \multicolumn{2}{|c|}{ Input transformer data } & $x$ \\
\hline Power, kW & 15 & $\nabla$ \\
\hline Input voltage, V & 380 & $\nabla$ \\
\hline Input frequency, $\mathrm{Hz}$ & 50 & $\nabla$ \\
\hline Transformation factor & 0.8 & $\nabla$ \\
\hline Effeciency & 0.8 & $\nabla$ \\
\hline Cost, c.u. & 100 & $\nabla$ \\
\hline Weifht, kg & 100 & $\nabla$ \\
\hline Height, mm & 100 & $\nabla$ \\
\hline Width, mm & 100 & $\nabla$ \\
\hline Depth, mm & 100 & $\nabla$ \\
\hline Change & & \\
\hline
\end{tabular}

Fig. 3. Window of transformer parameters of the DIMDrive software 


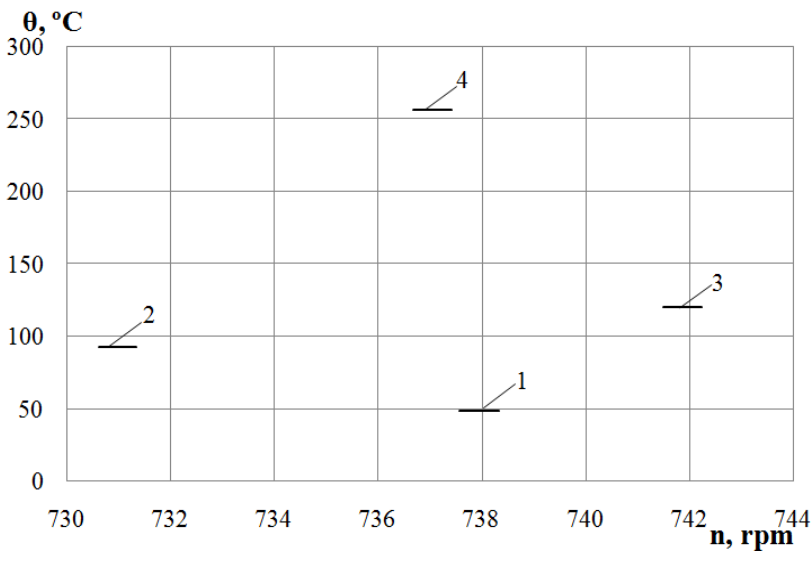

Fig. 4. Temperatures of motors' stator windings

Dynamic characteristics, which are dependencies of changes in electrical, energy values in time at the motor input, are presented in Fig. 5-8. The numbering of the characteristics corresponds to the variant numbering of the electric drives in Table 1. The code DIMDrive allows, when considering the dynamic characteristics, to exclude the starting mode from the presentation, which was done later. Similarly, the dynamic characteristics can be calculated at the input of the drive.

Table 1 shows the values of the indicators of the considered ED, which include the medium cyclic efficiency $\left(\eta_{m c}\right)$, the power factor $\left(\cos \varphi_{m c}\right)$, the reduced costs $\left(R C_{m c}\right)$, as well as the weight, size, and cost parameters of both the motors and the drives.

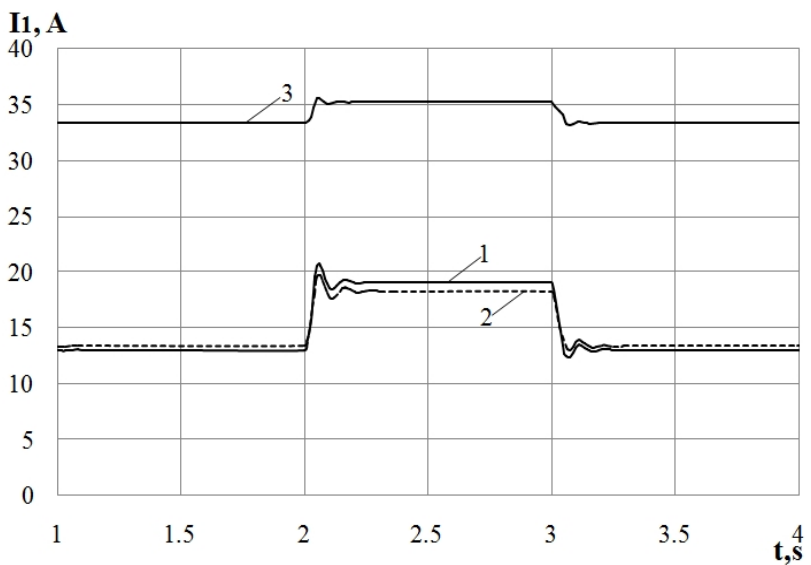

Fig. 5. Dependencies of currents consumed by motors

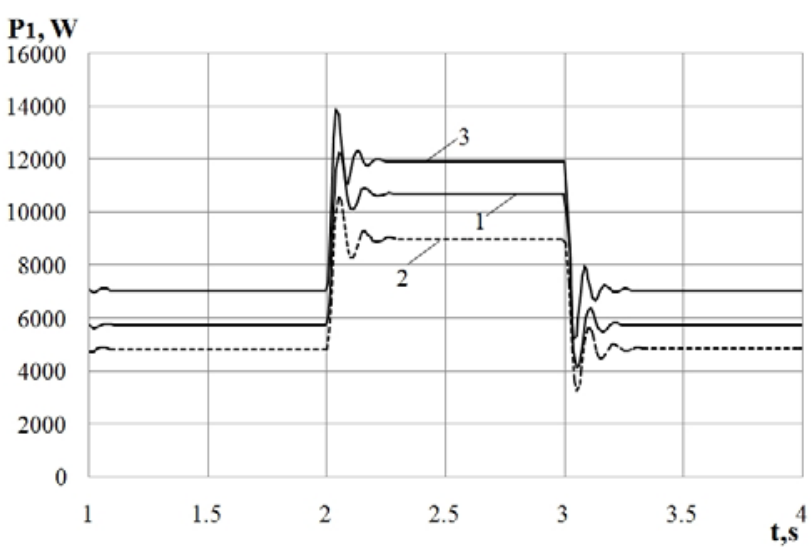

Fig. 6. Dependencies of active powers consumed by motors

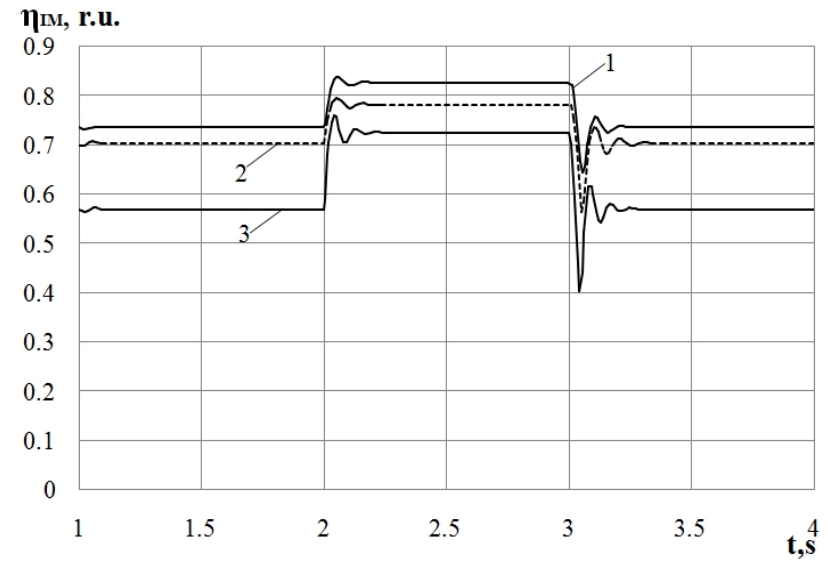

Fig. 7. Motors efficiency dependencies

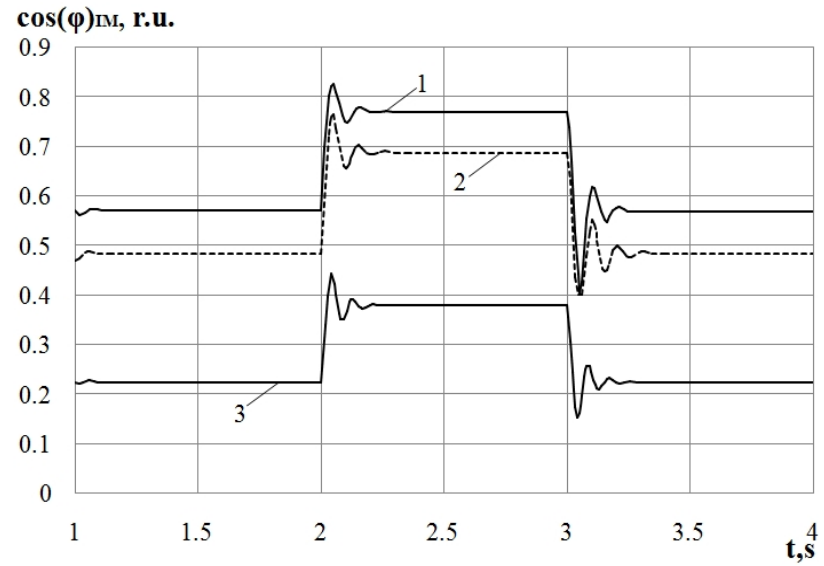

Fig. 8. Motors power factor dependencies

Table 1

\begin{tabular}{|c|c|c|c|}
\hline \multicolumn{4}{|c|}{ Comparison of various ED indic } \\
\hline $\begin{array}{l}\text { Indicators } \\
\text { and parameters }\end{array}$ & 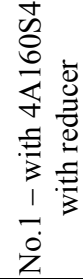 & 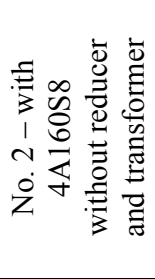 & 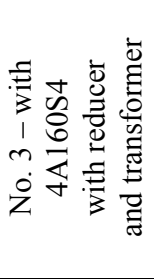 \\
\hline$\eta_{m c} \mathrm{IM}, \%$ & 76.54 & 72.89 & 62.16 \\
\hline $\cos \varphi_{m c} \mathrm{IM}$, r.u. & 0.636 & 0.551 & 0.276 \\
\hline$\eta_{m c} \mathrm{ED}, \%$ & 61.23 & 72.89 & 39.78 \\
\hline $\cos \varphi_{m c}$ ED, r.u. & 0.636 & 0.551 & 0.221 \\
\hline$R C_{m c} \mathrm{IM}, \mathrm{USD}$ & 2172 & 1980 & 3146 \\
\hline$R C_{m c} \mathrm{ED}, \mathrm{USD}$ & 2932 & 1980 & 5181 \\
\hline Mass of IM, kg & 118.9 & 111.8 & 118.9 \\
\hline Volume of IM, $\mathrm{dm}^{3}$ & 9.62 & 10.73 & 9.62 \\
\hline Cost of IM, USD & 642 & 552 & 642 \\
\hline Mass of ED, $\mathrm{kg}$ & 218.9 & 111.8 & 318.9 \\
\hline Volume of ED, $\mathrm{dm}^{3}$ & 10.62 & 10.73 & 11.62 \\
\hline Cost of ED, USD & 742 & 552 & 842 \\
\hline
\end{tabular}


The calculation of the cost of active energy loss per year can be performed:

$$
C_{a}=C \cdot T_{\text {year }} \cdot K_{L} \cdot P_{E D} \cdot\left(1+0.04-\eta_{m c E D}\right) / \eta_{m c E D},
$$

where $C=0.05 \mathrm{USD}$ is the price per $1 \mathrm{~kW} \cdot \mathrm{h} ; T_{\text {year }}=2100$ is the number of hours of ED operaton in the year; $K_{L}$ is the load factor (taken equal to 1.0 ); 0.04 is the relative value of losses in the consumer's distribution network.

Comparison of the considered ED variants at the cost of active energy losses for the year (Table 2) was made.

Table 2

Comparison of the cost of active energy losses of various ED

\begin{tabular}{|l|l|l|l|}
\hline & & & \\
\hline
\end{tabular}

\section{Conclusions}

1. The DIMDrive code has been developed, which allows analyzing the dynamic modes of operation of induction motors, including in electric drive systems with matching transformers and reducers, and this is the basis for designing motors for various operating modes.

2. For comparison of the efficiency of the considered electric drives, the medium cyclic criteria of the energy and cost groups are proposed, which take into account the corresponding indicators in both the steady-state and the transient modes.

3. Of the three considered electric drives, ED with 4A160S8 motor without a reducer and a transformer has the advantage for the following reasons:

- the highest value of the medium cyclic efficiency of the electric drive;

- the lowest value of the medium cycle reduced costs of the electric drive;

- the lowest value of the cost of active energy losses per year.

4. If the medium cyclic power factor of the electric drive is used as the selection criterion, then the ED with the 4A160S4 motor with a reducer has an advantage.

\section{REFERENCES}

1. IEC 60034-1:2004. Rotating electrical machines - Part 1: Rating and performance.

2. Bespalov V.Y., Dunaykina E.A. Moshchinskii Y.A. Nestatsionarnye teplovye raschety $v$ elektricheskih mashinah [Unsteady heat calculations in electrical machines]. Moscow, MEI Publ., 1987. 72 p. (Rus).
3. Dunaykina E.A. Razrabotka modifikatsii asinkhronnykh dvigatelei edinoi serii $4 A(H=56-132 \mathrm{~mm})$ dlia kratkovremennykh rezhimov. Avtoref. diss. kand. tekhn. nauk [Development modifications asynchronous motors single series $4 \mathrm{~A}(\mathrm{H}=56-132 \mathrm{~mm})$ for the short-term operation. Abstracts of cand. tech. sci. diss.]. Moscow, 1986. 20 p. (Rus).

4. Nyein Nyein Soe, Thet Thet Han Yee, Soe Sandar Aung. Dynamic Modeling and Simulation of Three-phase Small Power Induction Motor. World Academy of Science, Engineering and Technology, 2008, no.42, pp. 421-424.

5. Verbovoi A.P., Verbovoi P.F. Problems of modeling of transient electromagnetic processes in asynchronous machines. Technical electrodynamics. Thematic issue "Problems of modern electrical engineering», 2004, chapter 2, pp. 65-70. (Rus).

6. Kopylov I.P. Matematicheskoe modelirovanie elektricheskih mashin [Equipment of the electrode plants mathematical modeling of electrical machines]. Moscow, High School Publ., 1987. 248 p. (Rus).

7. Petrushin V.S. Asinhronnye dvigateli $v$ reguliruemom elektroprivode: Uchebnoe posobie [Induction motors in adjustable electric: Textbook]. Odessa, Nauka i tehnika Publ., 2006. 320 p. (Rus).

8. Zhao C., Ren Z., Zhou X., Wen B. The Online Monitoring of the Dynamic Characteristics for an Induction Motor and Gearbox Transmission System. Second International Conference on Innovative Computing, Informatio and Control (ICICIC 2007), Kumamoto, 2007. pp. 532-532. doi: 10.1109/ICICIC.2007.582.

9. Evon S., Schiferl R. Direct-drive induction motors: using an induction motor as an alternative to a motor with reducer. IEEE Industry Applications Magazine, 2005, vol.11, no.4, pp. 45-51. doi: 10.1109/MIA.2005.1458276.

10. Rojas-Moreno A. Parameter extraction of an induction motor with gearbox for dynamic simulation. 2016 IEEE ANDESCON, $\quad$ pp. $1-4 . \quad$ doi:

\subsection{9/ANDESCON.2016.7836207.}

11. Shwehdi M.H., Hye A., Quasem M.A. Economic analysis and evaluation of transformer and induction motor losses costs using PC software. 1993 (25th) Southeastern Symposium on System Theory, pp. 63-67. doi: 10.1109/SSST.1993.522743.

12. Petrushin V.S., Ryabinin S.V., Yakimets A.M. Analysis of losses and thermal state of an asynchronous motor in frequency control. Works of the Institute of Electrodynamics of the National Academy of Sciences of Ukraine, 1999, no.1, pp. 31-36. (Rus).

13. Petrushin V.S., Bendahmane Boukhalfa, Yakimets A.M., Kalenik O.V. Influence of magnetic core steel saturation and rotor current displacement on dynamic characteristics of adjustable-speed induction motors. Electrical Engineering \& Electromechanics, 2010, no.2, pp. 21-23. (Rus). doi: 10.2098/2074-272X.2010.02.06.

14. Tonkal V.E., Novoseltsev A.V., Denisiuk S.P. Balans energii $v$ silovykh tsepiakh [Balance of energies in power circuits]. Kiev, Naukova dumka Publ., 1992. 312 p. (Rus).

15. Rodkin D.I. The balance of the components of the instantaneous power of polyharmonic signals. Transactions of Kremenchuk Mykhailo Ostrohradskyi National University, 2007, no.3(44), part 1, pp. 66-71. (Rus).

16. Orlovskii I.A. On the power in an electrical circuit with a valve. Works of the Tavria State Agrotechnological University, 2013, no.13, vol.4, pp. 141-150. 
17. Petrushin V.S., Rjabinin S.V., Yakimets, A.M. Programmnyj produkt «DIMASDrive». Programma analiza raboty, vybora $i$ proektirovanija asinhronnyh korotkozamknutyh dvigatelej sistem reguliruemogo elektroprivoda [Program performance analysis, selection and design of asynchronous cage motors controlled drive systems]. Patent UA, no.4065. (Ukr).

Received 29.08.2018
${ }^{1}$ Odessa National Polytechnic University, 1, Shevchenko Avenue, Odessa, 65044, Ukraine, phone +380487058494 , e-mail: victor_petrushin@ukr.net,

rostik-enok@ukr.net, nikita_prokopenko@yahoo.com

${ }^{2}$ HWR Berlin,

Alt Friedrichsfelde 60, 10315 Berlin, Germany, phone +49 (0)30 30877-2443,

e-mail: juriy.plotkin@hwr-berlin.de

V.S. Petrushin ${ }^{1}$, Doctor of Technical Science, Professor,

Y.R. Plotkin ${ }^{2}$, Candidate of Technical Science, Professor,

R.N. Yenoktaiev ${ }^{1}$, Postgraduate Student,

N.S. Prokopenko ${ }^{1}$, Master of Science,

How to cite this article:

Petrushin V.S., Plotkin Y.R., Yenoktaiev R.N., Prokopenko N.S. Research of dynamic characteristics of induction motors in electric drives with matching transformer and reducer. Electrical engineering \& electromechanics, 2019, no.2, pp. 14-20. doi: 10.20998/2074-272X.2019.2.03. 